\title{
Experimental Studies on the Insulin Producing Activity of the Islet of Langerhans in Aged Rat
}

\author{
M. KYOGOKU and K. OKAMOTO \\ Department of Pathology, Faculty of Medicine, Kyoto University, Kyoto, Japan
}

There has been a number of experimental results that the glucose tolerance of the aged people is lower than that of young people. However, there are still a number of controversies about the real cause of such an unusual glucose metabolism. In this presentation we are going to inform some results of our attempt to clarify the reason of such retarded tolerance, with a stress on the insulin producing activity of islet of Langerhans.

The histological study of the pancreas of the human over 80 -year-old revealed; 1) arteriosclerosis, 2) interlobular fibrosis especially around the vasculature and islet, 3) atrophy of the islet, 4) regeneration of the islet cells around the old islet, forming peculiar shape of the islet.

The pancreas of the rat over 18-month-old showed the same tendency, but the fibrosis was not so remarkable.

The average of the glucose tolerance curve of the aged rat (over 18-month-old) showed somewhat retarded glucose metabolism, however, the divergency of each curve was the most striking phenomenon in this experiment, that is, some curves were almost the same as that of young adult rat, but some were almost similar to the diabetic curves. Therefore, in the following experiments we selected the rat with abnormal GTT curves.

According to Hellman et al., the number of $\beta$ cells decreases considerably from the age of around 540 days.

We checked the mode of insulin mobilization from $\beta$ cells by the aid of FITC labeled antiinsulin globulin. In young adult rat the localization of insulin in $\beta$ cells was very homogeneous and dense, and the $\beta$ cells in smaller islet contained more insulin than those of larger islet.

The islet of the aged rat contained less insulin; not only less in each $\beta$ cells, but also the distribution of insulin-containing $\beta$ cells over each islet was unequal. In general, $\beta$ cell in the regenerated part of islet contained more insulin. Some islets contained a number of lipofuscin granules. At an hour after injection of glucose in the peritoneal cavity, the insulin granules moved to the periphery of each $\beta$ cell of aged rat. After 2 hours very coarse granules of insulin reappeared in some of the $\beta$ cells.

Enzyme-histochemically, the islet of aged rat showed less activity of acid phosphatase, G-6-P dehydrogenase and succinic dehydrogenase.

Electron microscopical studies of the $\beta$-cells of aged rat reveal cystic changes of ER, mitochondria as well as Golgi's apparatus in some of the $\beta$ cells. Such changes were very 
close to those of the experimental congenital diabetic rat (OKAMOTO). Large lysosome with peculiar shape was seen in the cytoplasma. Proliferation of the collageneous fibre around the capillaries was another characteristic feature of the aged islet.

The uptake rate of ${ }^{3} \mathrm{H}$-cystine or -leucine into the islet of Langerhans was checked in vivo and in vitro. By the case of in vitro experiments, the isolated islets by Lacy's method were incubated in vitro with various concentration of glucose as well as the ${ }^{3} \mathrm{H}$-amino acid. The uptake of such amino acid in the islet of aged rat was always lower than that of young rat, however, the ability to synthesize new insulin seemed to be still left in the cell activity when the concentrated glucose was mixed in the culture medium.

As a conclusion, some of the aged rats over 18 months showed retarded glucose consumptions. In such animals, the insulin content in the islet was always less than that of young rat. Probably because of the degenerative changes and/or functional disturbances of their $\beta$ cells. Some parts of the islets revealed an evidence of limited regeneration of the $\beta$ cells and in such parts the cells still have almost the same ability to react to the stimuli and synthesize new insulin as the young rat. But on the whole, the islet of the aged rat showed less activity to produce insulin than that of the young rat.

(See pp. 810 820) 


\section{Studies on the Relation Between Aging and Endocrine Secretion of Pancreas and on the Impairment of Carbohydrate Tolerance in the Aged}

\section{K. KOSAKA}

Department of Internal Medicine, Tokyo Women's Medical College, Tokyo, Japan

The followings are the results of the present investigation.

A. The relation between aging and secretion of insulin.

1. The value of serum IRI at fasting state in healthy subjects neither increased nor decreased with age.

2. Insulin response of the serum in oral $100 \mathrm{~g}$ glucose tolerance test was similar between the aged (more than 50 years of age) and the youth (between 20 and 39 years of age), depending on the type of glucose tolerance curve. The capacity of insulin secretion after the administration of glucose in the aged was comparable to that in the youth.

3. Insulin response of the serum after glucose-glucagon-tolbutamide administration (intensive islet stimulation test) in the aged was lower and more retarded than that in the youth, and was similar to that in mild diabetes.

B. The impairment of glucose tolerance in the aged.

1. The percentage of those who had low glucose tolerance increased with age.

2. The changes of blood sugar, serum IRI and NEFA in the aged who had low glucose tolerance were not essentially different from those in young diabetics, and their metabolic states were considered to be diabetic.

(See pp. 821 822) 


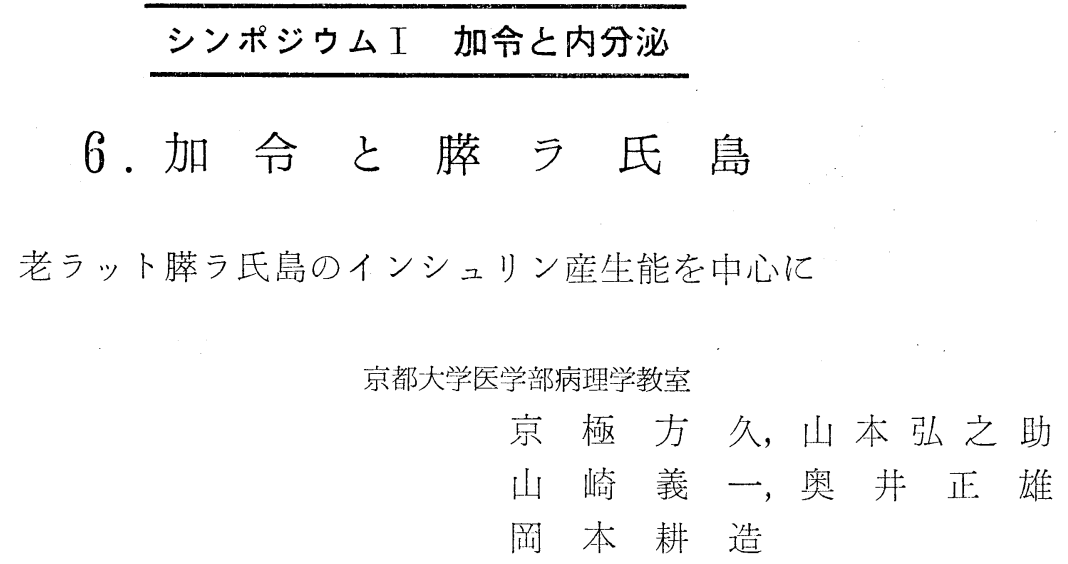

1920年 Spence ${ }^{1)}$ の報告以来，高命者の糖忍容力の低下については少なくない報告がある ${ }^{2) 3747) . ~ し か し ~}$ その原因についての検討はまだ十分とはいえないように思われる。それは一つにはとトにせよ動物にせよ個 体差劫強く，その時間的な年令と，個体，細胞の実際の加令の度とは必ずしも平行していないてと，またヒ トの場合には，その上に極めて多種の遺伝因子，環境因子が加わつて，それに対する反応が極めて複雑であ るととなどが，問題を混乱させている主要な因子と考えられる。動物実験の場合には，ての後半の理由は比 較的容易に一定化出来る。もちろんネズミとヒトの糖代謝が完全に同一であるとはいえないが，条件をきめ 易いという動物笑験の利点を活用して得た 2 〜の新しい知芫をこてに報点したい.

さて糖忍容力の異常を来たす原因は解糖に関係する全身すべての部分にあると思われる。しかし時間の制 限もあるので今回は，「膵ラ氏島」そのもの，それも主として $\beta$ 細胞内のインシュリンの動きに限り，また 手技も出来るだけ新しいものを用いて，今までに明らかにされていない方面を追求しようとつとめた.

\section{I 人体例高令者の膵ラ氏島所見 (H.E. 染色)}

まず順序として最初に30例の80才以上の人体例の膵ラ氏島の普通染兒による所見につてい述べる。われわ れの手元にある膵の材料はいずれも剖検例であり，なんらかの「死に至る病」を有していて決して純粋な形 の加令現象が現われているとはいえない.しかしその中から大体全部に共通の所見として見られるものは，

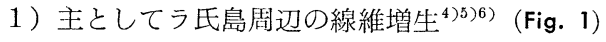

2 ）ラ氏島の萎縮

3 ）膵央質内の細小動脈硬化（Fig. 1)

4 ）やや変形した大きなラ氏島の出現（Fig. 2) 等である.

\section{II 老令ラットの膵ラ氏島所見 (H.E. 染色)}

次にラットについては，京大医学部純采動物センターから分与された Wistar 系ラットを恒温・恒湿の動 物小屋で CLEA の固型飼料で飼育して18ケ月（540日）以上生存した約50匹について検討した。 H.E. 染色 で見た限りでは大体に人体例程強い所見は出ていないが，やや菱縮気味なのや，毛細管周国に線維化のある （Fig. 3）ラ氏島が見られ，一部には血管璧の肥厚，外分泌部の線維増生が兒られる。しかし一番特徵的な のは次々に芽を出して行くように，すなわちタコの足状に大きく拡がうたラ氏島の現われることであろう (Fig. 4). (紊極・山崎)

\section{III 老ラットの血糖曲線}

体重 $100 \mathrm{gm}$ 当り $200 \mathrm{mg}$ のブドー糖を腹腔内に注射して後の值糖の動きを時關的に追つて，いわゆる GTT 
Fig. 9. Glucose tolerance test curves of the 20-week-old "young" rats

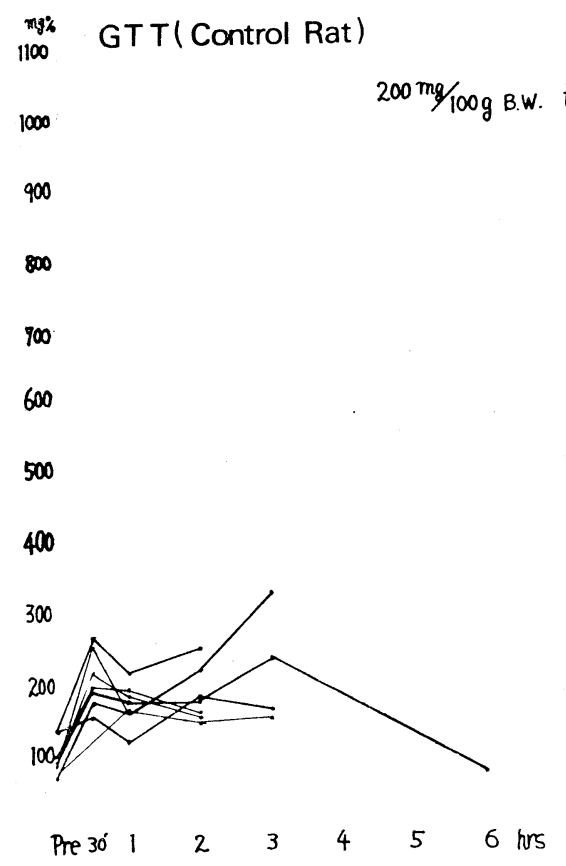

Fig. 10. GTT curves of the 77-week-old "aged" rats. The type of curves varies from normal to diabetic

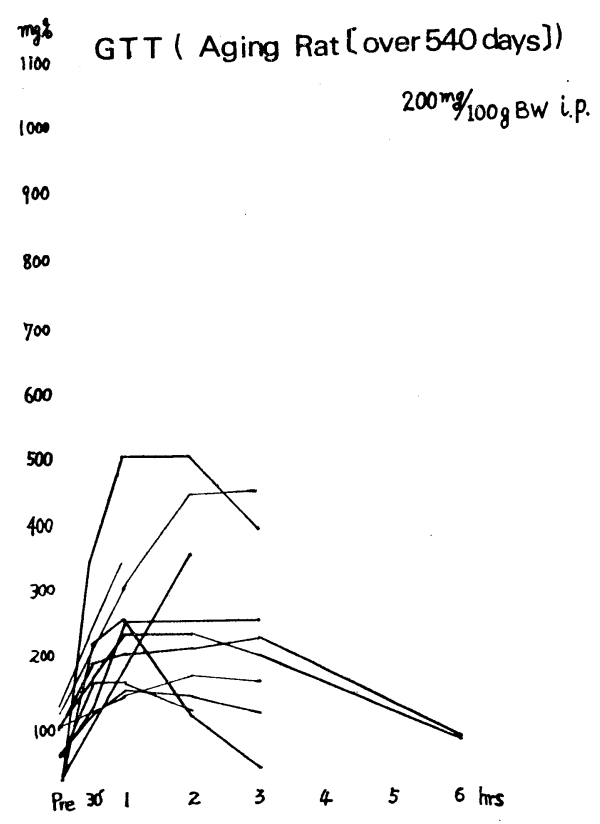

Fig. 11. GTT curves of the "alloxan diabetic" rats

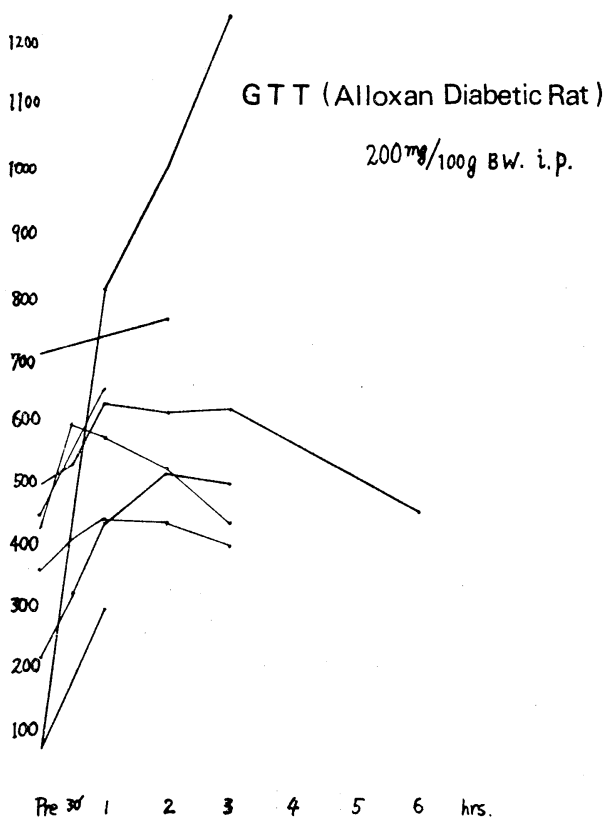

Fig. 12. Mean value curve of each of these three groups. GTT curve of aged rat come to the middle between normal and diabetic curves. And besides, it shows some absorption disturbance of the intraperitoneally injected glucose

$$
\text { G T T (平均佂) }
$$$$
200 \mathrm{mg} / 100 \mathrm{gBW} \text { i.p. }
$$

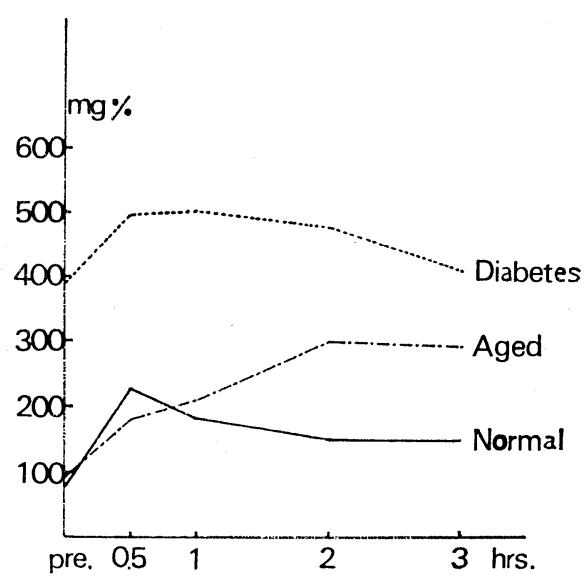


曲線を描いた。血糖測定は Somogyi-Nelson 法によつた。生後約半年たつた若い成熟 (young adult) ラット と Alloxan 糖尿病ラットと老令 (Aging) ラットの三群はそれぞれ Fig. 9, 10，11 のようである。 その平 均值が Fig. 12 であつて，てれによると，ラットでも老化と共に糖忍容能は低下しているのがわかる。しか してれを個々の動物について見ると(Fig. 10)，その中にも比較的糖尿病型に近い，すなわち，血糖の恢復が 非常に遅れる型と，正常に近いのとが混在しているととがわかる，それで以後の実験には出来るだけての血 糖曲線の異常な動物を用いた。（山崎）

\section{（IV） ラ氏島 $\beta$ 細胞亡 Aging（螢光抗体法による研究）}

Hellman ${ }^{8)}$ その他多のく人の研究によると, Aging も540日以上になるとラ氏島内 $\beta$ 細胞数が急に減少す

Fig. 13. The ratio of the number of $\beta$ cells to that of $\alpha$ cells decreased considerably in the rat of more than 69-week-old. In general, smaller islet contains more $\beta$ cells.

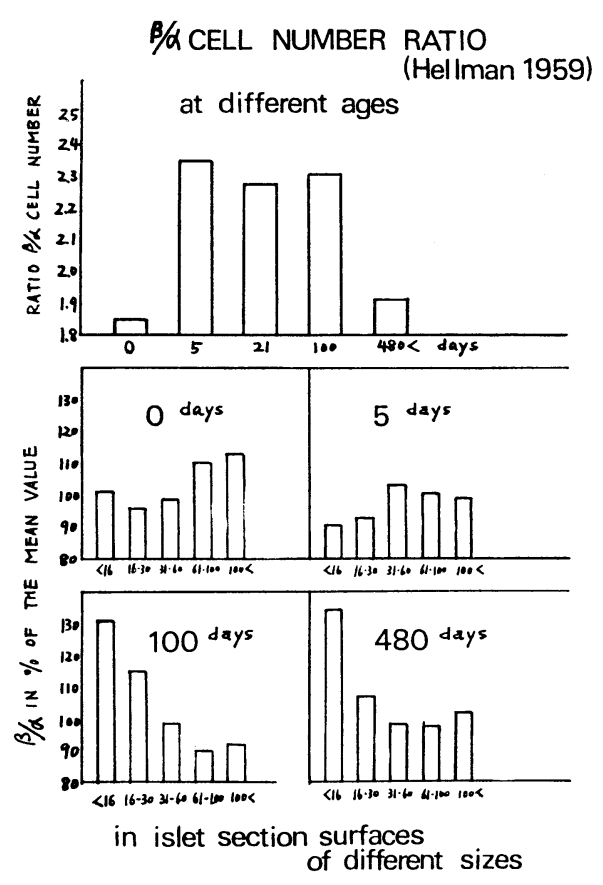

るとされている (Fig. 13)。そのさい $\beta$ 細胞の数が減少 するのみなのか, あるいはその中の $\beta$ 顆粒すなわちイ ンシュリンも減少するのか，あるいはインシュリンを 動員するメカニズムに異常はないのかというような点 を螢光抗体法で追跡しようと考えた。

\section{実験方法}

ブタの結晶インシュリンをモルモットの皮下に毎週 2 回 $0.1 \mathrm{mg}$ づつ注射し，てれを10ケ月くり返して得 た抗血清の粗グロブリン分画に，Gitlin 法で FITC を 標識し精製したものを, 膵の凍結切片上で反応させて 観察した9). 動物は特殊なものを除き，18時間絶食さ せたのち断頭により屠殺し直ちに膵組織を剔出凍結し た. 耐糖試験を行なつたものはそれぞれの所定の時間 に屠殺した。

\section{研究の結果}

18時間絶食させ, 安静にしておいた若い成熟ラット のラ氏島では 1 コ 1 コのインシュリン量に差がある. 一般的には，小さいラ氏島ほどインシュリン保有細胞 が多く, かつその胞体内インシュリンの分布も全体と して平等である (Fig. 14)。大きなラ氏島では，インシ ュリン保有細胞の占める割合がやや低く, 個々の細胞 内のインシュリンの量も少なく，かつ不平等である (Fig. 15).

他方, 老令ラットのラ氏島では, 外分泌部には消耗 色素の自家螢光を大量に示すのにラ氏島自身には大し た変化のないものから (Fig. 16)， $\beta$ 細胞の数も，その

中のインシュリン量も少ないものまである (Fig. 17).

また既述の奇怪な形をした大きなラ氏島では，周辺の方の怖らく新生したと思われる部分以外のインシュ リン量は極めて少ないのが普通である(Fig. 18)。 Lipofuscin の非常に多いラ氏島も見られる．てのように インシュリンを比較的多く含む細胞が大きなラ氏島の中のでく一部に限られるのは普通の大きさのラ氏島の 中にも見られる。一方軽症の Alloxan 糖尿病ラットでは大きなラ氏島の中の僅か 2 2 3 コの細胞中にのみ インシュリンが存在し，しかも普通とやや異なつて粗大な顆粒状に見られる (Fig. 19)。 また私共のところ で作成した実験的先天性糖尿病ラットのいわゆる prediabetic stage に当るものの膵ラ氏島においては数ב の細胞に片寄つてインシュリンが多く見られるととは Aging の場合と幾分似ている (Fig. 20，21). 
次にてのような動物に $200 \mathrm{mg} / 100 \mathrm{gm}$ B.W. のブドウ糖を腹腔内に投与して見ると，1時間目には，若い ラットのラ氏島は全体として輪郭が少しほややけてくる。しかしインシュリン量には著しい違いがない (Fig. 22)．老ラットでは細胞周辺のインシュリン濃度が濃くなつて来る(Fig. 23，24).

Alloxan 糖尿病ではすべてのラ氏島からインシュリンが全くなくなつてしまう (Fig. 25).

糖負荷後 2 時間目になると，またインシュリンは新たに生産されるらしく，若いラットではラ氏島全体が 非常に強く光り出してくる(Fig. 26)，老ラットでもほほ同様の傾向で光り方が強くなつてくるが，その際 多くはその顆粒の大きいのか特徵である (Fig. 27)。老ラットに特徴的なあの奇怪な形の大きなラ氏島でも インシュリンの新生が始まつてくる (Fig. 28)。しかし Alloxan 糖尿病例では新生は極めて弱い(Fig. 29)。

以上の螢光抗体法による追求でいえることは絶食安静状態の老命ラットのラ氏島のインシュリン量はたし が少ない. 消耗色素の非常に多いものもあるし, ラ氏島内の一部の細胞のみが働いていると思われる状態 が多い，てのような時期には血糖值も低い，とてろがてれに大量の糖を負荷するとインシュリンはかなりの 量が新たに作られるようである。すすなわちいわゆる予備力（reserve power）はかなり残つているのである. しかしそのインシュリン新生は決して正常のように平等に行なわれるのではなくて粗大顆粒状になつたり一 部に片寄つて行なわれる。この点若干糖尿病症例に似たとてろもあるとい光よう。(京極)

\section{V ラ氏島の酵素組織化学}

次に若干の酵素組織化学的研究結果を示す。乙れらの酵素は直接インシュリンの合成に関係あるものばか りではないが解糖系あるいは燐酸化といつた一般的な細胞の代謝反応窑接な関係を有する醉素ばかり 5 種 である ${ }^{11) .}$ その結果調べた 3 匹すべてが同様の傾向を示したのは酸性フォスファターゼ（Fig. 5，6，7，8）, ブドウ糖一6ーリン酸脱水素酵素，コハク酸脱水素酵素の三種でいずれも活性の低下を示した。簡単にい えば, Aging の所見は正常と糖尿病症例の中間所見を示す。その一覧表が Table 1 であつて全体として の傾向は実験的糖尿病の所見に似ていて:それよりも軽度であるといえよう。てれら酵素についてはさらに Isozyme として追求する必要があるものと考えている．(山本）

Table 1. Enzyme histochemical findings of pancreatic islets of aged, alloxan diabetic and experimental congenital diabetic rats

\begin{tabular}{|c|c|c|c|c|c|c|c|c|c|c|}
\hline & \multicolumn{4}{|c|}{ Aged Rats } & \multicolumn{4}{|c|}{ Alloxan Diabetic Rats } & \multicolumn{2}{|c|}{$\begin{array}{l}\text { Experimental } \\
\text { Congenital Diabetic Rats }\end{array}$} \\
\hline & 1 & 2 & 3 & $M$ & 1 & 2 & 3 & $M$ & Prediabetic Period & Diabetic Period \\
\hline$A C P_{\text {ase }}$ & $\downarrow$ & $\downarrow$ & $\downarrow$ & $\downarrow$ & $\downarrow \downarrow$ & $\downarrow \downarrow$ & $\downarrow$ & $\downarrow \downarrow$ & $\uparrow \uparrow$ & $\downarrow \downarrow$ \\
\hline ATP ase & $\downarrow$ & $\rightarrow$ & $\downarrow$ & $*$ & $\downarrow$ & $I$ & $\downarrow$ & $\downarrow$ & $\downarrow$ & $\downarrow$ \\
\hline G6PD & $\downarrow$ & $\downarrow$ & $\downarrow$ & $\downarrow$ & $\downarrow \downarrow$ & $\downarrow$ & $\downarrow \downarrow$ & $\downarrow \downarrow$ & $\uparrow$ & $\downarrow \downarrow$ \\
\hline LD & $\rightarrow$ & $I$ & $\downarrow$ & 4 & $\rightarrow$ & $\downarrow$ & $\downarrow \downarrow$ & $\downarrow$ & $\uparrow$ & $\mp$ \\
\hline$S D$ & \pm & $I$ & $\downarrow$ & $\div$ & $\mp$ & $\downarrow \downarrow$ & $\downarrow \downarrow$ & $\downarrow \downarrow ?$ & no activity? & no activity? \\
\hline
\end{tabular}

$\uparrow \uparrow, \downarrow \downarrow:$ Marked changes $\rightarrow, \pm$ : Very slight changes
$\uparrow, \downarrow:$ Moderate changes $\rightarrow$ : Indistinct changes

ACPase (Acid phosphatase) : Takamatsu (1956)

ATPase (Adenosine triphosphatase) : Wachstein, Meisel (1957)

G-6-PD (G-6-P dehydrogenase) : Nachlas, Walker, Seligman (1958)

LD (Lactic dehydrogenase) : Hess, Scarpelli, Pearse (1958)

SD (Succinic dehydrogenase) : Nachlas, Seligman (1957) 


\section{$\mathrm{VI}$ 老ラットラ氏島の電顕像}

まず GTT カーブのあまり異常でない例のブドウ糖投与 1 時間目の電顕像は Fig. 30 のようで, empty sac の多い細胞や，大きい不視則な形の恐らくLipofuscin と思われる Lysosome の存在が目立つ程度で (Fig. 31)，あまり強い変化や異常は見られない.

しかし GTT 曲線に強い異常の見られる動物の $\beta$ 細胞では Fig. 32〜35のように不視則な cystic structure の形成の兒られるものが多い．乙れらの多くは小胞体から出来たもののようであるが，之トコンドリアの一 部の膨化したものかとも思われるものや，empty sac の集りや，Golgi 装置の拡がつたと思われるもの等 も見られる.またとれらの細胞の間に Collagen が侵入してきているとと, 特に血管周囲にそれの多いてと も老化の一つの特徴である (Fig. 33，35).

以上をまとめると Table 2 のようになる。いずれも皆非特異的な退行性の変化であつて，決して，Aging

Table 2. Ultramicroscopical characteristics of the islet of aged rat

1. Proliferation of collagenous fibre around the intra-islet capillary.

- 2. Some irregular dilation of the endoplasmic reticulum of $\beta$ cells.

- 3. Swelling and vacuolation of some mitochondrien of $\beta$ cells.

4. Decrease in number of $\beta$ granule.

$\bigcirc$ 5. Appearance of large atypical lysosome in $\beta$ cells

6. Pyknosis ? of $\alpha$ cells

findings specific for aging

- more remarkable in the rat with abnormal GTT curves.

にのみ現われる特徴的なものはないし ${ }^{12)}$ ，またすべての $\beta$ 細胞がてのような高度な退行性病変を有している のではなく，全く正常のものもそうとう沢山見られるわけである. (京極)

\section{VII 放射性アミノ酸のとり込み}

次に腹腔内に注射された ${ }^{3} \mathrm{H}$-Cystine のとり込みのオートグラフによる追求結果を報告する，インシュリ ンには Cystine が多く含まれているととは揫知の通りである。他方とれはグルカゴンには含まれていない. もちろん細胞構成蛋白には Cystine は必ず含まれているが，ラ氏島だけに限つていえば，Cystine のとり 込みの多い細胞はインシュリン合成になんらかの関係がある細胞と見てよいと思われる。

${ }^{3} \mathrm{H}$-Cystine の $100 \mu \mathrm{Ci}$ を老ラットの腹腔内に注射し30分後に屠殺, 膵藏を直ちに Carnoy 氏液固定, ア ルコールでよく洗いながら型のようにパラフィン包埋し，その切片に Dipping 法で原子核乳剤をカバーし， 4 週間の露出後 D-19 で現像する ${ }^{9)}$. 研究の結果若い動物のとり込み方え゙老ラットのそれより強いととが 明らかであつた．外分泌部にも若干の差があるが，若年と老年両者の差は内分泌部において最も顕著である。 ラ氏島の細胞の中でも特に Grain の多い細胞が怖らく $\beta$ 細胞であろう.

この際問題になるのはこのような差は， $\beta$ 細胞の機能の差だけによるのではなく，注射された後，腹腔 $\rightarrow$ 血管 $\rightarrow$ 血管床 $\rightarrow$ 細胞と移動する間のあらゆるStep そおける差の綜合の現われであるふら，ての中間のStep を除いて純粋にラ氏島のみの機能を見る目的で行なつたのが次の実験である。（京極）

\section{Lacy et al 法で isolate したラ氏島の放射性アミノ酸のとり込み}

1967年に Lacy \& Kostianovsky ${ }^{13}$ ) の発表した方法 (Collagenase を用いる方法) によりラ氏島を遊離さ せ，乙れを短期間培䬭してその Medium の中に ${ }^{3} \mathrm{H}$-(トリチウム) 標識アミノ酸を入れ，液中の糖の濃 度をかえて ${ }^{14)}$ ，それによるアミノ酸のとり込みの変化をシンチレーションカウンターで定量的に追つて見る (Fig. 36)と， (Fig. 37) のようになる. 
Fig. 36. Method of the experiments using isolated Langerhans' islet. The rat was anesthetized with Nembutal and its pancreas was perfused thoroughly with neutral red containing saline. Several milliliter of Hanks' solution was infused with pressure in to the pancreatic duct, and thus the dissociated pancreatic tissue was incubated with collagenase, getting isolated pink stained islet by decantation of digested exocrine pancreas. The isolated islets were incubated in the modified KrebsRinger solution with ${ }^{3} \mathrm{H}$-leucine and glucose solution of various concentration for 30 minutes at $37^{\circ} \mathrm{C}$. After solubilization of the islets by Soluene, the amount of incorporated ${ }^{3} \mathrm{H}$-leucine was detected by liquid-scintillation spectrometer.

\section{METHOD FOR THE ISOLATION OF THE ISLETS OF LANGERHANS \\ (Lacy \& Kostianovsky 1967)}

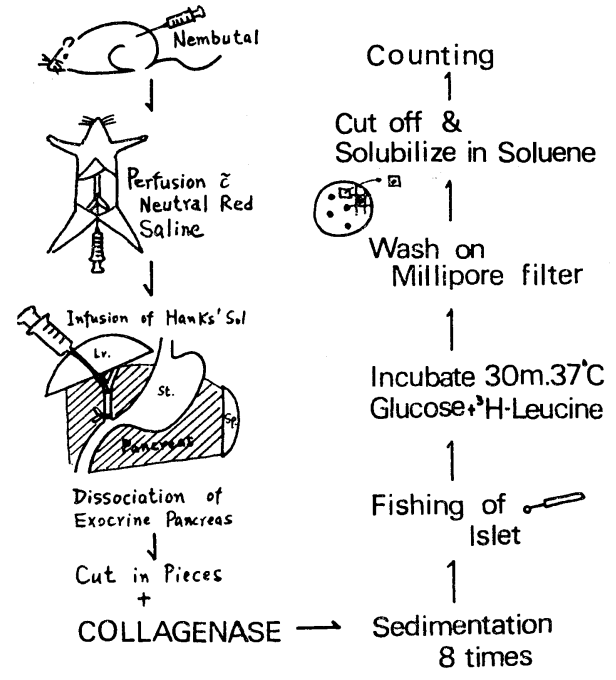

${ }^{3} \mathrm{H}$-Leucine uptake in the isolated islet

\begin{tabular}{|c|c|c|}
\hline & NORM. & AGED \\
\hline $\begin{array}{cc}\text { Average number of islet } \\
" & \text { DPM / Organ }\end{array}$ & $\begin{array}{r}196 \\
18,872\end{array}$ & $\begin{array}{r}133 \\
10,117\end{array}$ \\
\hline
\end{tabular}

Fig. 37A. The number of islet in the pancreas of aged rat (133) is about $30 \%$ less than that of young rat. On the other hand, the amount of incorporated ${ }^{3} \mathrm{H}$-leucine is about $45 \%$ less in aged rat (10117 DPM) than in young rat (18872 DPM).

Fig. 37B. On the stand-point of per islet, the incorporation of ${ }^{3} \mathrm{H}$-leucine in the islet is always lower in case of aged rat. However, when the concentration of glucose in the cultured medium becomes denser, the incorporation of ${ }^{3} \mathrm{H}$-leucine into the aged islet increases with the same ratio as the young rat. It probably means, that the islet of aged rat still has enough reserve power to produce new insulin, when some urgent metabolic attack was loaded over the aged individual.

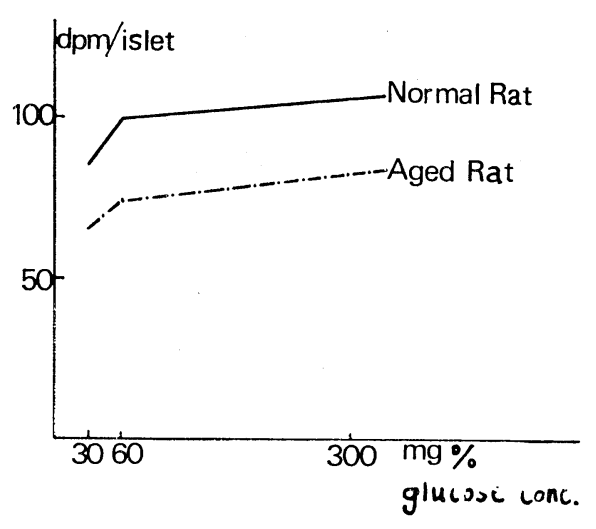

すなわち膵全体としても (Fig. 37A), 単位ラ氏島当りとしても (Fig. 37B), 安静時活動時を通じて ミノ酸のとり込みは老ラットの方が若年ラットより確かに低い. しかしてれにブドウ糖を負荷してその濃度 が濃くなるにつれてのとり込みの増加率で見ると老令ラットのとり込みの増加率は若年ラットのそれと殆ん ど変らない(Fig. 37B)。すなわち反応性は殆んど変つていないというととが明らかになつたものと思う。し かし老令ラットのとり込み沈決して若年ラットのそれを上まわることはない.（京極・奥井） 


\section{IX ま と め}

以上を綜合して次のようにいえると思われる，老令のラットの中には糖忍容能の低下しているものがあり， てのような動物では形態的にも機能的にも膵ラ氏島のインシュリン合成及び保有度は，全体として見ると， 絶食安静時には低下している。乙れは，体の他の部分にも起つているのであろう細胞の老化変性過程が基盤 になつているものと思われるが，一方ではてれに対して再生その他で（タコの足様ラ氏島）ての低下した機 能を代償する努力がなされている．その結果大量のブドウ糖の負荷を加えると，ある程度反応し，正常とあ まり変らない程度のインシュリンの新生を行なう。しかしブドウ糖負荷前のインシュリン量が少ないととも あつて流血中の糖の処理は少しおくれるのであろう。しかし老ラットのラ氏島の能力は最終的には決して若 年ラットのそれにまで及ぶてとはない，てれは恐らく身体全体としてそれだけの糖の消費を必要としない程 度まで代謝率が低下しているからであろうかと解釈する。

謝辞：終りに本発表の機会を与えて載いた，会長七条小次郎教授，座長西川文夫教授に哚い感謝を捧げま す。また, 本研究の技術的援助をして載いた原田孝之, 浅田孝子, 後藤美恵子, 溝睹, 多田良之助, 上田完 二，堀田一枝諸兄妹に深く感謝致します。

\section{文献}

1) SPENCE, J.C. : Some observations on sugar tolerance with special reference to variations found at different ages. Quart. J. Med., $14: 314$, (1921).

2) PORTER, E. and LANGLEY, G.J. : Studies in blood sugar. Lancet, 2, 947, (1926). 3) 村地悌二: 糖尿病の年令的考察. 日老医誌 1 : 167，(1926）。4）村地㣢二：老化現像としての糖㽷病は考えられるか. 日本臨床，25：193，(1967). 5）沢田皓史, 福永安一郎, 村地悌二：老年者の糖代謝之膵ラ氏島の組織像任関する研究, 日本医誌, 5 : 146, (1968). 6) 福永安一郎：糖代謝の年令的変化化関する研究. 日老医誌，5:147, (1968). 7）小坂樹徳，羽倉綾子，斉藤玲子：老年者における䌅代謝障害について。綜合臨床，17：420，(1968). 8) HellmaN, B. : The relation between age and the $\beta / \alpha$ cell ratio in the islet tissue of the rat. Acta Endocrinologica, $31: 80-90,(1959)$. 9) 浜島義博, 京極方久: 免疫組織学 (改訂 2 版). 医学書院, 東京, (1968). 10) OKAMOTO, K. : Induction of diabetic disposition and of spontaneous diabetes in the descendants of diabetic animals. Proc. Iind Internat. Cong. Endocrinol. (London). p. 1018, Exc. Med. Found., Amsterdam, (1964).

11）武内忠男, 清水信夫, 小川和朗：醭素組織 化学. 朝倉書店, 東京, (1968). 12) 横尾定美：櫒亏氏島内分泌之粘尿病。綜合臨床, $17: 382$, (1968). 13) LAGY, P.E. and KOSTIANOVSKY, M. : Method for the isolation of intact islets of Langerhans from the rat pancreas. Diabetes, 16:35, (1967).

14) VANCE, J.E., BUCHANAN, K.D., GHALLONER, D.R. and WILLIAMS, R.H. : Effect of glucose concentration on insulin and glucagon release from isolated islets of Langerhans of the rat. Diabetes, $17: 187$, (1968). 


\section{Explanation of Plates}

Fig. 1. The pancreas of 82-year-old male human died of lung cancer. Fibrosis is seen around the sclerotic arterioles and islet. (HE stain $\times 100)$

Fig. 2. Pancreas of 80-year-old female human died of stomach cancer. Islet with peculiar shape is demonstrated here. (HE stain $\times 100)$

Fig. 3. This picture reveales fine fibrosis around the capillary in the islet of 80 -week-old "aged" male rat. (HE stain $\times 100)$

Fig. 4. This picture shows an islet with peculiar shape which was probably formed as a result of regeneration of islet cells around the old mother islet of "aged" rat. $($ HE stain $\times 100)$

Fig. 5 Acid phosphatase reaction in the pancreatic islet of 20-week-old "young" male rat. (Takamatsu's method $\times 100$ )

Fig. 6. Acid phosphatase reaction in the pancreatic islet of 72-week-old "aged" rat. Enzyme activity is lower than that of fig. 5. (Takamatsu's method $\times 100$ )

Fig. 7. Acid phosphatase reaction in the islet with peculiar shape which was seen in the pancreas of 76-week-old "aged" rat. Notice the low enzyme activity similar to fig. 6 . (Takamatsu's method $\times 100$ )

Fig. 8. Acid phosphatase reaction in the islet of alloxan diabetic rat. Islet is very small and the enzyme activity is quite low. (Takamatsu's method $\times 100$ ) 
Fig. 14. Insulin localization in the islet of young male rat in his 24-hour-fasting and resting state. The ratio of the number of insulin-containing cells to other cells is quite high, and the concentration of insulin is quite dense. (Immunofluorescent technique $\times 160$ )

Fig. 15. Insulin localization in the giant islet of young rat in 24-hour-fasting and resting state. The ratio of insulincontaining cell number in the islet is quite low and the concentration of insulin is light and unhomogenous. (Immunofluoresent technique $\times 160)$

Fig. 16. Insulin localization in the islet of aged rat in 24-hour-fasting and resting state. Almost the same pattern of insulincontaining cells as is seen in young rat. Fluorescent particles in the exocrine parts are lipofuscin. (Immunofluorescent technique $\times 160$ )

Fig. 17. Most of the islets in the aged rats show this kind of pattern. The insulin is in an ununiform and granular shape. (Immunofluorescent technique $\times 160$ )

Fig. 18. In the islet of peculiar shape, the insulin containing cells situate mostly in their periphery, where the islet cells seemed to be regenerated. Aged rat. (Immunofluorescent technique $\times 160)$

Fig. 19. By the case of alloxan diabetes, insulin is granular and only seen in one or two cells per islet. in 24-hour-fasting and resting state (Immunofluorescent technique $\times 400$ )

Fig. 20. The number of insulin-containing cells in the islet of experimental congenital diabetic rat (OKAMOTO) is relatively few and the mode of localization is uneven and rough granular. in 24-hour-fasting and resting state (Immunofluorescent technique $\times 400)$

Fig. 21. Islet in auother case of experimental congenital diabetic rat. Almost the same pattern as fig, 20 in the similar state. (Immunofluorescent technique $\times 400$ ) 
Fig. 22. Islet of the normal young rat, which was administerd intraperitoneally with $200 \mathrm{mg} / 100 \mathrm{~g}$ BW glucose. At an hour after injection, the islet showed almost the same pattern as fig. 14. except the vague contour of these cells. (Immnnofluorescent technique $\times 400)$

Fig. 23. Insulin-containing cells of the islet of aged rat, which was subjected to the same treatment as fig. 22. Insulin is granular and located at the periphery of cytoplasma. (Immunofluorescent technique $\times 400$ )

Fig. 24. Insulin-containing cells of the giant islet of aged rat, which was subjected to the same treatment as fig. 22. (Immunofluorescent technique $\times 160$ )

Fig. 25. The islet of alloxan diabetic rat, which was subjected to the same treatment as fig. 22 , does not contain insulin at all. (Immunofluorescent technique $\times 400$ )

Fig. 26. When two hours past after intraperitoneal injection of glucose, considerable amounts of granular insulin appears again in the islet of young rat. (Immunofluorescent technique $\times 160)$

Fig. 27. Even in the case of aged rat the islet cells still have an ability to produce new insulin. The newly synthetized insulin is granular in shape when two hours are over after glucose injection, (Immunofluorescent technique $\times 400$ )

Fig. 28. The islet with peculiar shape in the aged rat also have an ability to produce new insulin. However, the insulin producing cells get together at the periphery like colony. (Immunofluorescent technique $\times 160$ )

Fig. 29. In case of alloxan diobetic rat, the survived few cells show weak but steady response against the glucose loading. (Immunofluorescent technique $\times 400$ ) 
Fig. 30. Electron microscopic picture of $\beta$ cells of aged rat, which showed almost normal GTT curve. Notice a number of empty sac and immature granule. ( $\times 3600$ )

Fig. 31. Another electron microscopic picture of the same animal as fig. 30. Lysosome of peculiar shape (Lipofuscin?) is seen at the center of picture. ( $\times 6000)$

Fig. 32. Electron microscopic picture of $\beta$ cells of aged rat, which showed abnor mal (diabetic ?) GTT curves. In the lower half of the picture appear a number of vesicles, most of which seems to be the dilated endoplasmic reticulum. Golgi's apparatus also dilates considerably at the top left of the picture. $(\times 3600)$

Fig. 33. Electron microscopic piture of islet of the same case. Degeneration of mitochondrien of $\beta$ cells and the proliferation of collagenous fibre around the intra-islet capillary are noticed. $(\times 3600)$

Fig. 34. Electron microscopic picture of islet of another aged rat with similar GTT pattern. At the top left prolifeation of collagen, at the right side an pyknotic $\alpha$ cell and at center partially vacuolated $\beta$ cell are noticed. $(\times 3600)$

Fig. 35. Another part of the same section as fig. 34. Two vacuolated $\beta$ cells at top right and bottom left, one pyknotic $\alpha$ cell at center and proliferated collegenous fibre at bottom right are noticed. $(\times 3600)$ 


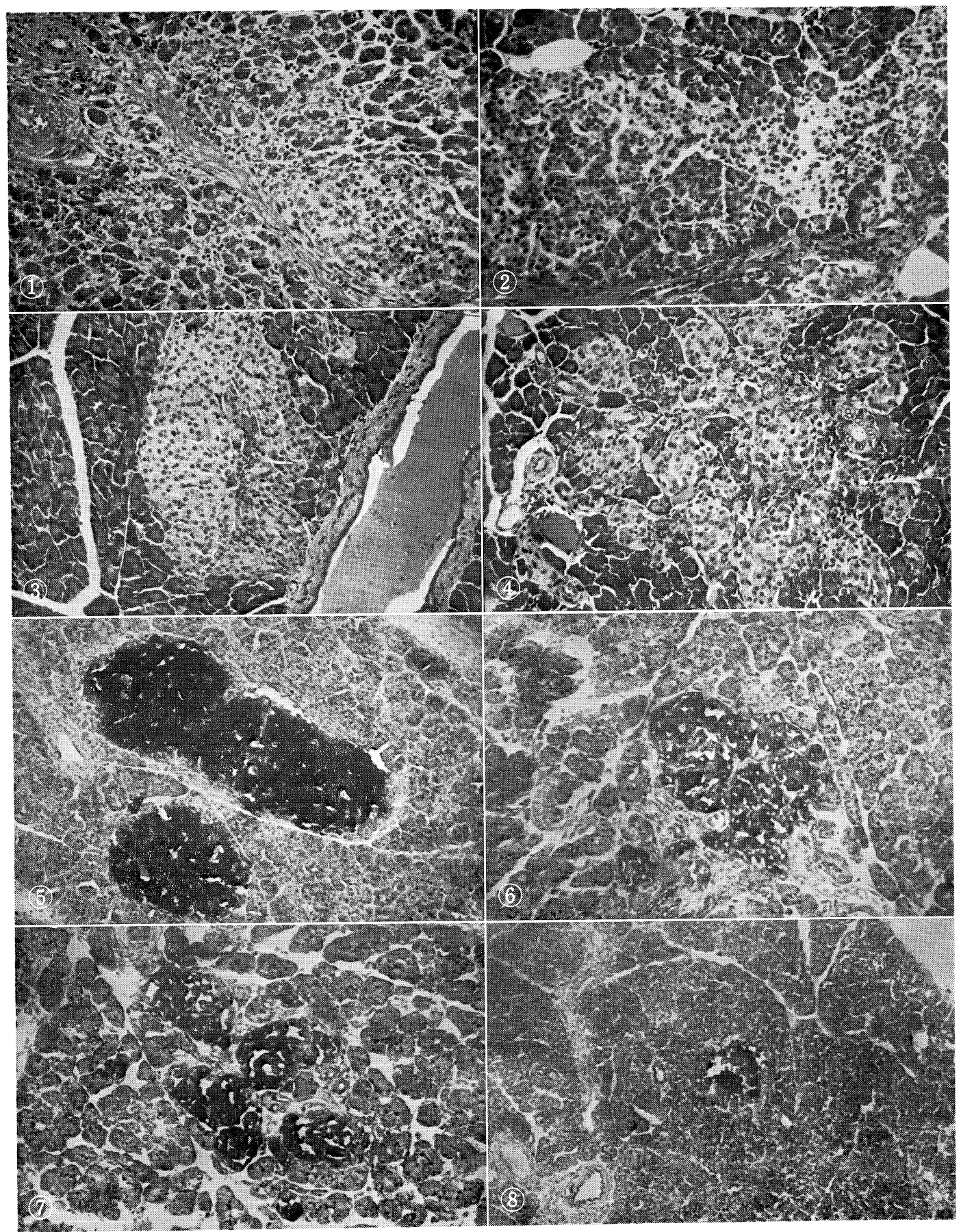


京極 論 文附図（その2）

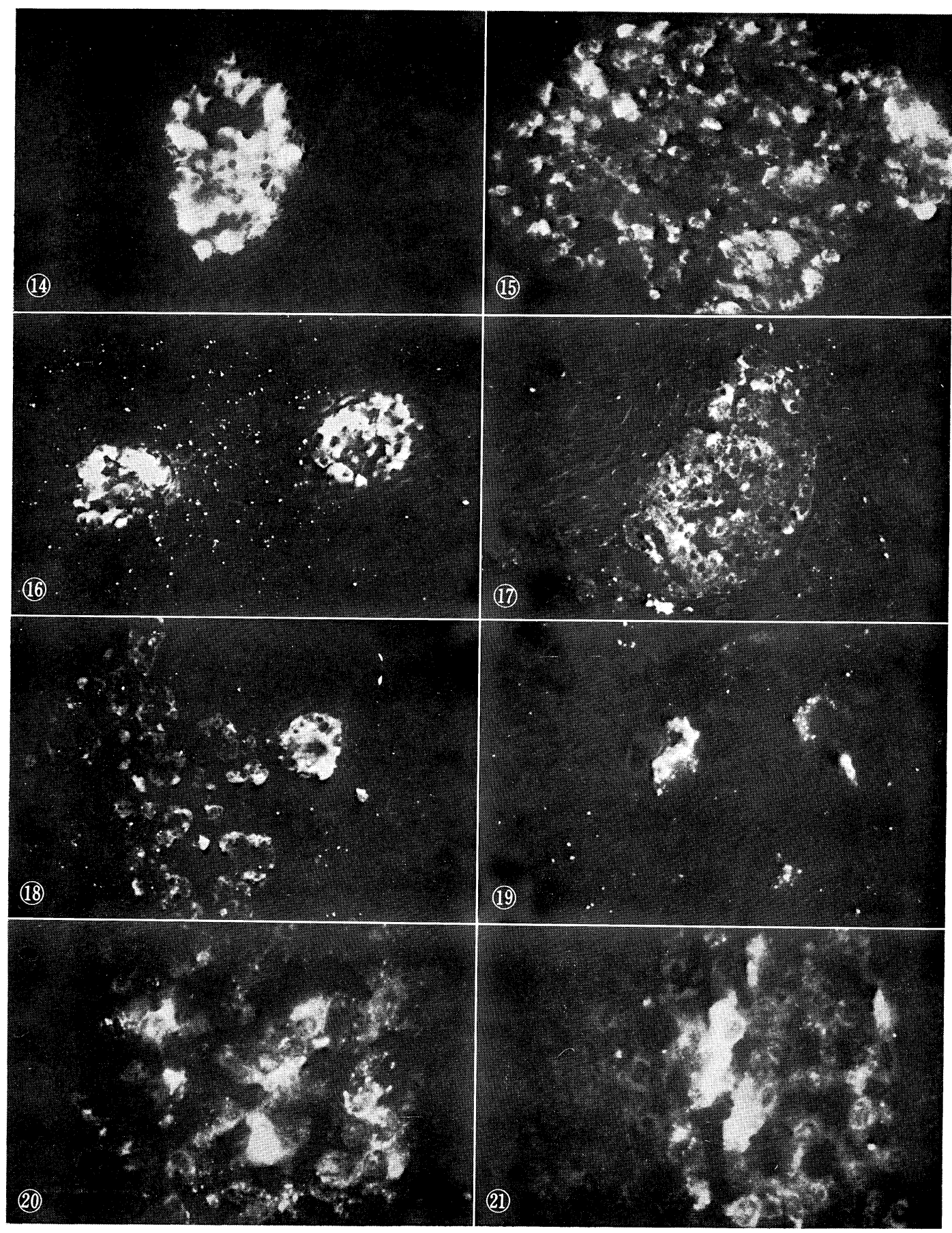


京極 論文附図（その 3 ）

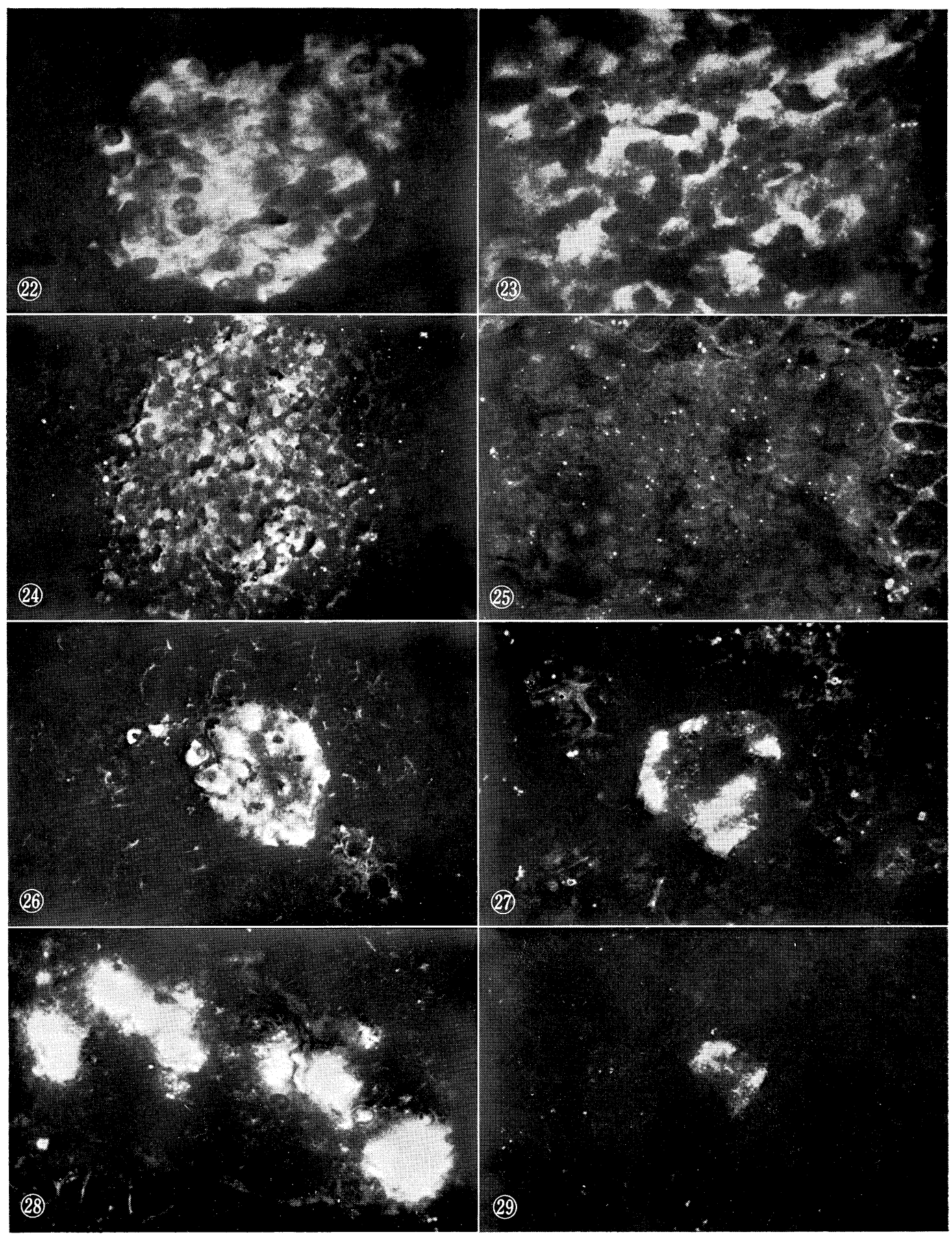




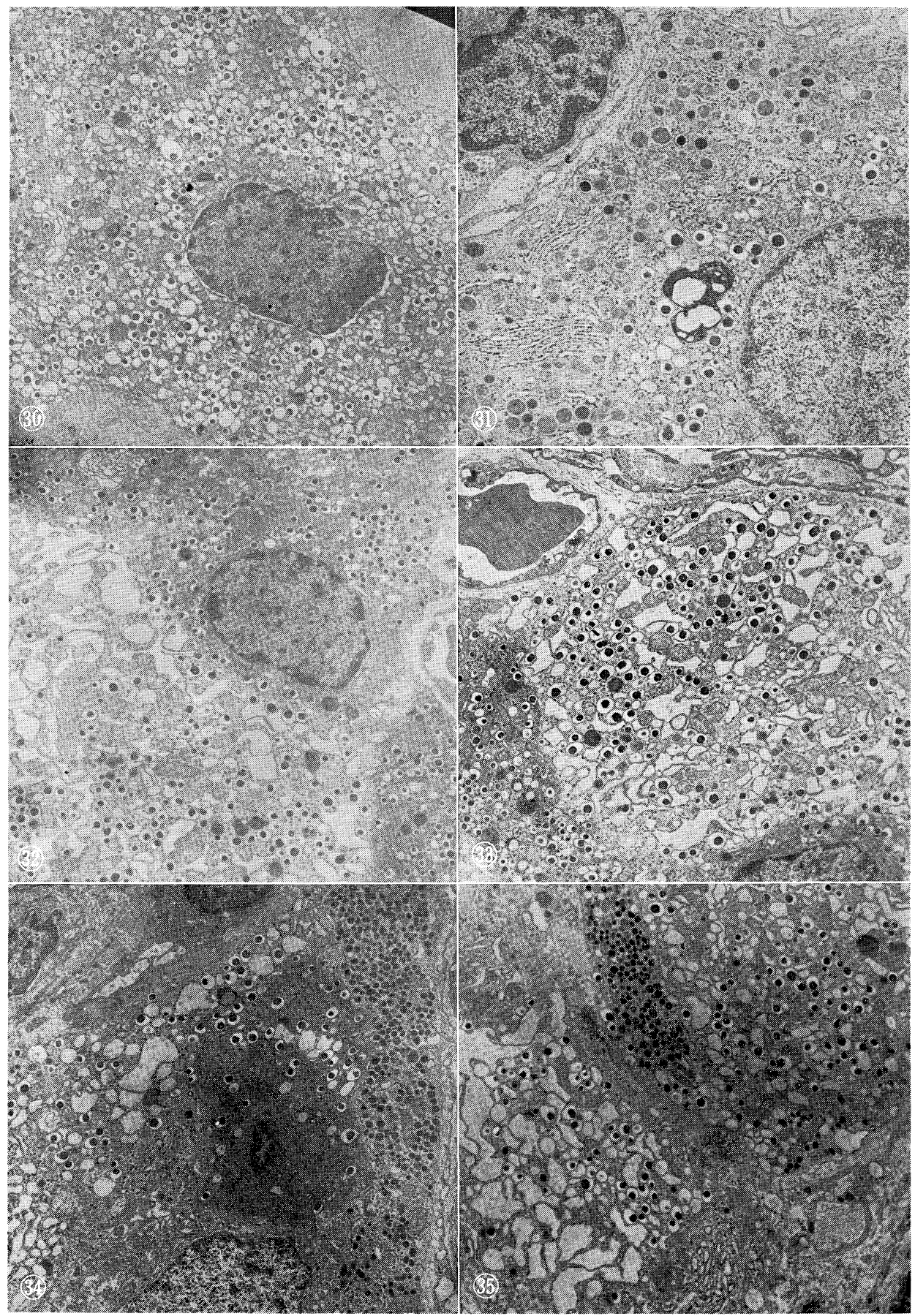




\title{
追 加 発 言
}

\author{
加令と膵内分泌並びに老年者にみられる \\ 糖忍容力低下について
}

東京女子医科大学内科
小 坂 樹 德

\section{加令とインスリン分泌}

膵内分泌には，インスリンとグルカゴンを論すべきであろうが，てとではインスリンのみを取上げる。

(1) 空腹時血中インスリン

空腹時血中インスリン・レベルは, 代謝の比較的安定した時の $\beta$ 細胞の機能をうかがい知る意味で重要で ある。糖代謝異常を招くとされる疾患をできるだけ除外した所謂健康者の空腹時インスリンは $10 \pm 5 \mu \mathrm{U} / \mathrm{ml}$ で，てれを10代毎に区分してみたが，加令と共に上昇または低下すする事実はなかつた。

（2）グルコース負荷後の血中インスリン動態

血中インスリン動態の異常は，グリコース負荷後の反応にみられ，それは， $\beta$ 細胞のインスリン分泌をか なりよく反映するものである.

一見健康とみられる107名（各年代毎に10数名）にグリコース $100 \mathrm{~g}$ を経口投与し，その後の血中インスリ ンの動きを調べた。乙の際の血中インスリンの動きは，一般にその時の血糖曲線に影響される事実にかんが み，血糖曲線の型別に著年者（20３9才）と老年者（50才以上）を比較したが，インスリン反応には老若間 に有意差はなかつた。すなわちグルコース負荷後の老年者のインスリン分泌能は若年者のそれに匹敵するも のであつた。

（3）グルコース，グルブタマイド負荷後の血中インスリン動龍

Ryan らは, グルコース $100 \mathrm{~g}$ 経口投与 30 分後に, グルカゴン $1 \mathrm{mg}, \quad$ トルブタマイド $0.5 \mathrm{~g}$ を速かに静注 した後の血中インスリンの動きを追究し，てれを intensive islet stimulation test とよんだ。若年者では, グルカゴン, トルブタマイド静注直後血中インスリンは $600 \mu \mathrm{U} / \mathrm{ml}$ に達し, 比較的速かに下降したが，老 年者では頂值が低く，前值への恢復が幄延し，軽症糖尿病者のそれと類似の反応であつた．

グルカゴン，トルブタマイドによるインスリン分泌促進の機序は，それぞれグルコースのそれと異り，主 として貯蔵インスリンの急速な放出効果とみなされている点を考え，興味ある知見と考えられる。

\section{老年者にみられる糖忍容力低下について}

(1) 加令と糖㤎容力

糖尿病の家族歴, 既往歴のない健康者にグルコース $100 \mathrm{~g}$ を与光, 国際糖尿病学会の基準で判定した糖忍 容力低下者の頻度は, 加令之共に増加した。

(2) 糖忍容力低下を示した老年者の代謝位相

加令と共に糖忍容力低下をを示すものが増加するのは, 加令現象の一表現か, 病的現象（糖尿病）とみなす べきかは重要な問題である。

この点に関し, グルコース負荷後 30 分間における血糖, インスリン NEFA の動きの相互関係を検討した。 血糖上昇汇対するインスリン增加の比は，血糖曲線糖尿型病の老年者が，正常型の老年者より低い值を示し 
たが，乙れは若年糖尿病と若年正常者のそれと同じ関係にあつた。血糖上昇に対する NEFA 下降の割合， インスリン上昇に対するNEFA 下降の割合も，程度の差てそあれ，それぞれ類似の関係を示した。いいか えれば若年者糖尿病の示す比が，正常者のそれに較へ減少または増加する場合，老年糖㽷病型，正常型のそ れも同様に減少または増加した，従つてグルコース負荷 30 分間にわける血糖，インスリン，NEFA の動態 からみる限り， 糖尿病型血糖曲線を示した老年者の代謝位相も primary diabetes と同じく diabetic な状 態にあるものとみてよからうと考光られた。

更にてれまでのわれわれのこの方面の研究は，かかる状態は，ある種の異常に対する生体の共通な適応反 応の表現の 1 つとも見做しうる現象であろうとの推論を可能にした。

\section{文献}

小坂樹徳：血中インスリンからみた糖尿病の成因と臨床 第17回日本医学会学術講演（1967年の日本の医 学) III : 135, 1967.

羽倉棱子, 斉藤玲子, 大森安恵, 小坂樹徳 : 老年者における糖代謝障害とその意味するもの 日本臨床 $26: 608,1968$.

塚本房江，下重正子，大森安恵，羽倉棱子：糖尿病患者における Glucose-Glucagon-Tolbutamide Test 糖尿病 $11: 297,1968$.

追加：阪大西川内科 垂井清一郎 Glucose tolerance test は，今日と雖も糖尿病の臨床診断上最も重要な 手段であるが，「GTT の低下」 equal「糖尿病」とはもはや考觉られていない，てのととは，糖㽷病とは 何ぞやという基本的な問題にもつながつている，即ち，糖尿病は代謝異常の一種であるが，代謝の pattern が一つの方向へまとまつて整然と偏移する所に大きな特徽があり, 耐糖能の低下は糖新生能の六進と表裏一 体として発現するものと考えられる.

てのような観点からすると, 加令によつて, 耐糖能の低下があつても, たとえば動物における観察で 肝 G-6-Pase の低下が知られているように，糖新生能も同時に低下していると，果しててれを diabetic state と呼ぶべきか大きな疑問がある，糖尿病内服剂による低血糖が老人に多いととを考虑すると，老人の糖代謝 については耐糖能の低下だけでなく糖新生能の低下も問題にすべきと思われ，また老人における糖尿病の診 断は慎重でなければならない。

そこで，老年者における耐糖能の低下と真の意味の糖尿病を如何に区別するかという問題が重要となる. この問題の最終的な解決が現段階において困難としても, ぞのような方向で私共は努力すべきか, 御教示頂 ければ幸いと存じる。 